\title{
Factors Determining Sago Starch Import Demand: Empirical Evidence from Japan
}

Author(s): Marlisa Ayu Trisia, Hironobu Takeshita, Mayumi Kikuta, Hiroshi Ehara

Source: Journal of International Logistics and Trade 2020; 18(4):159-167

Published by: Jungseok Research Institute of International Logistics and Trade, Inha University

DOI: https://doi.org/10.24006/jilt.2020.18.4.159

The Journal of International Logistics and Trade is an official journal published by Jungseok Research Institute of International Logistics and Trade, Inha University, Korea. JILT welcomes manuscripts that advance the practice and science of logistics, trade, and other related fields.

Frequency: Quarterly (March, June, September, December)

Stable URL: https://www.ejilt.org

The Jungseok Research Institute of International Logistics and Trade is a specialized academic research institute representing Inha University and the Inha Foundation in Korea. The institute aims to become a representative institute in Northeast Asia in the research of logistics and trade.

Stable URL: https://jrieng.inha.ac.kr

(C) Copyright. Jungseok Research Institute of International Logistics and Trade.

This is an Open-Access article distributed under the terms of the Creative Commons Attribution NonCommercial License (http://creativecommons.org/licenses/by-nc/4.0/) which permits unrestricted noncommercial use, distribution, and reproduction in any medium, provided the original work is properly cited 


\title{
Journal of International Logistics and Trade
}

J. Int. Logist. Trade, 2020, Vol. 18, No. 4, 159-167

pISSN : 1738-2122 eISSN : 2508-7592

https://doi.org/10.24006/jilt.2020.18.4.159

https://www.ejilt.org

\section{ARTICLE}

\section{Factors Determining Sago Starch Import Demand: Empirical Evidence from Japan}

\author{
Marlisa Ayu Trisia ${ }^{1,}{ }^{*}$, Hironobu Takeshita ${ }^{2,3}$, Mayumi Kikuta ${ }^{2}$, Hiroshi Ehara ${ }^{1,2}$ \\ ${ }^{1}$ International Center for Research and Education in Agriculture, Nagoya University, Nagoya, Japan \\ ${ }^{2}$ Applied Social System Institute of Asia, Nagoya University, Nagoya, Japan \\ ${ }^{3}$ Department of Plant Production Science, Graduate School of Bioagriculture Sciences, Nagoya University, Nagoya, Japan
}

\author{
Received July 17, 2020 \\ Revised November 09, 2020 \\ Accepted December 14, 2020 \\ *Corresponding author: Marlisa Ayu Trisia \\ International Center for Research and \\ Education in Agriculture, Nagoya \\ University, Nagoya, Japan \\ Tel: +81-52-789-4240 \\ Fax: +81-52-789-4225 \\ E-mail: trisiayu@agr.nagoya-u.ac.jp
}

\begin{abstract}
Sago starch (Metroxylon sagu Rottb.) is one of the starches imported into Japan. Recently, sago starch has been promoted as a healthy type of starch because it is gluten-free and non-allergenic. This study aims to identify the factors affecting sago starch import demand during the period 1978-2017 in Japan by using a double logarithmic linear function. The study revealed that the price of sago starch, GDP, aging population rate and tariff-rate quota policy are significant factors influencing sago starch importation in Japan.
\end{abstract}

Keywords Determinant factors, Import, Demand, Japan, Sago starch

\section{Introduction}

Starch is considered an important item for the food processing industry in Japan. It is used as a binders, thickener, and stabilizer in the food \& beverage industry. According to statistical data of the Ministry of Agriculture, Forestry and Fisheries, total starch consumption in Japan in 2017 was 2.6 million tons. Meanwhile, the starch production was 2.4 million tons, mainly from potato and sweet potato. This shortfall in supply led Japan to import starch to cover the demand. In 2017, Japan accounted for about $2.2 \%$ of the world starch imports and $10 \%$ of the world chemically-modified starch imports (OEC 2017).

One of the starches imported into Japan is sago starch. Sago starch is a starch obtained from the trunk of sago palm (Metroxylon sagu Rottb.), which is called "sago yashi" in Japan. In Southeast Asia and Melanesia, sago starch has long been used as a staple food (Takamura 1990) and a source of cash income for local communities (Chew et al. 1999). It produces high yields of dry starch between 150-300 kg per plant (Ehara 2009; Konuma 2018) and can be cultivated in marginal lands such as wetlands and peatland where other food crops cannot be grown economically. In 2017, Japan imported 13,546.8 tons of sago starch from Malaysia, 77\% of the total imported, and the rest from Indonesia (4,032 tons). In Japan, sago starch is used as dusting flour for noodles, dumpling skins, starch sugar, and dextrin (Takahashi et al. 2015). Recently, sago starch has been promoted as a healthy type of starch in Japan because it is gluten-free and non-allergenic. A study stated there is a possibility that demand for sago starch will increase depending on how it is marketed, especially where the aging of the population and preference for healthy foods are likely to continue (BFPRO 2016). Therefore, the import of sago starch will likely increase in the future.

In order to secure stable sago starch imports, it is necessary to establish an information system regarding supply-demand, and to promote food negotiation. However, the empirical studies on the import of sago starch in Japan are still limited. The majority of the studies on sago starch that are available are concerned with cultivation, production management, and utilization (Anugoolprasert et al. 2012; Ehara 2001; Trisia et al. 2017). Hence, this study investigates the key factors affecting the import demand of sago starch in Japan for the period of 1978-2017. In the following section, we cover the data source and methodology of our study. Empirical results are presented and discussed in Section 3, leading to our conclusions in Section 4. 


\section{Material and Method}

\subsection{Model specification}

The model adopted in this study is based on economic theory in the context of import for a country. Goldsten and Khan (1974) and Khan (1985) stated that the import demand is determined by the amount of import demand, the price of the imported product, and the country's income. Furthermore, it has been used by researchers to examine the Japanese market for imports through interaction between import demand, domestic real income, and import price (Tang 2008). Therefore, this study draws from those references.

The main import demand model is only the quantity of import demand, domestic real income, and import price. However, Hong (1999) stated that other factors could be incorporated within those factors theoretically. Other factors that have frequently been suggested in the literature as the determinants of import demand include population, substitute product, foreign exchange rate, domestic production. Thus, our first model integrates the real import quantity and price, GDP per capita, exchange rate, aging population rate, and domestic production. Meanwhile, the quantity of imported cassava starch is added as a substitute for sago starch in our model together with tariffication policy. The variables in the empirical model of the equation and its expected effect were defined in Table 1. By assuming degree zero homogeneity and infinite supply elasticity, the sago starch import demand functions can be estimated as per equation (1):

$$
\text { QS: f (SP, GDP, EXR, DP }{ }_{t-1}, \text { CSV, AGING, PL) }
$$

where QS is the quantity of sago starch import (ton), SP is the price of imported sago starch (yen/ton), GDP is the real income per capita as representing real disposable income (yen), EXR is real foreign exchange rate, $\mathrm{DP}_{\mathrm{t}-1}$ is lagged domestic starch production (ton), AGING is the aging population rate (\%) and CSV is the quantity of imported cassava (ton) respectively. Finally, PL as a tariffication policy (dummy variable) is imposed on imported sago starch to account for unusual periods.

A double-logarithmic linear function is applied for modeling and determine the demand functions in this paper. Several studies revealed that a double-logarithmic linear function was favored in import demand analysis models, such as import demand for meat (Goktolga 2006), import demand for dairy products (Karkacier 2000), import demand for vegetable oil and

Table 1. Variable definitions for imported sago starch in Japan

\begin{tabular}{|c|c|c|c|c|}
\hline Variable & Variable definition & $\begin{array}{l}\text { Expected } \\
\text { effect }\end{array}$ & Rationale & References \\
\hline SP & The real price of imported sago starch & - & $\begin{array}{l}\text { Price of sago starch affects } \\
\text { import demand }\end{array}$ & $\begin{array}{l}\text { Goktolga 2006; Hyuha et al. 2017; } \\
\text { Kizilaslan and Kizilaslan 2006; } \\
\text { Tanyeri-Abur and Rosson 1996; } \\
\text { Uzunoz and Akcay } 2009\end{array}$ \\
\hline GDP & $\begin{array}{l}\text { The real gross income domestic } \\
\text { product per capita }\end{array}$ & + & $\begin{array}{l}\text { The real income that the average } \\
\text { Japanese consumer has at their } \\
\text { disposal per given year }\end{array}$ & $\begin{array}{l}\text { Ahad et al. 2017; Baiyegunhi and } \\
\text { Sikhosana 2012; Hyuha et al. } 2017\end{array}$ \\
\hline EXR & Foreign exchange rate & + & $\begin{array}{l}\text { Ability to import depending on } \\
\text { the currency of the country }\end{array}$ & $\begin{array}{l}\text { Goktolga 2006; Hyuha et al. 2017; } \\
\text { Kizilaslan and Kizilaslan 2006; } \\
\text { Uzunoz and Akcay } 2009\end{array}$ \\
\hline $\mathrm{DP}_{\mathrm{t}-1}$ & Lagged domestic starch production & - & $\begin{array}{l}\text { Domestic starch production in } \\
\text { Japan in the previous year will } \\
\text { negatively affect product demand }\end{array}$ & $\begin{array}{l}\text { Feleke and Kilmer 2009; Hyuha et } \\
\text { al. } 2017\end{array}$ \\
\hline CSV & $\begin{array}{l}\text { The quantity of imported cassava } \\
\text { starch }\end{array}$ & - & $\begin{array}{l}\text { Quantity of cassava starch } \\
\text { influences product demand }\end{array}$ & Baiyegunhi and Sikhosana 2012 \\
\hline AGING & $\begin{array}{l}\text { A percentage of aging population rate } \\
\text { in Japan }\end{array}$ & + & $\begin{array}{l}\text { Elderly population size affects } \\
\text { market demand }\end{array}$ & $\begin{array}{l}\text { Baiyegunhi and Sikhosana 2012; } \\
\text { Hyuha et al. } 2017\end{array}$ \\
\hline PL & $\begin{array}{l}\text { Policy for tariff-rate quota on } \\
\text { imported starch (dummy, } 0=\text { no } \\
\text { tariff-rate quota for 1978-1994, } 1= \\
\text { tariff-rate quota for 1995-2017) }\end{array}$ & $+/-$ & $\begin{array}{l}\text { Import quota system was } \\
\text { introduced by WTO in 1995, } \\
\text { which represents a change in the } \\
\text { policy regarding imports of } \\
\text { starch in Japan }\end{array}$ & Choi and Sumner 2000 \\
\hline
\end{tabular}


products (Kizilaslan and Kizilaslan 2006), import demand for wheat (Baiyegunhi and Sikhosana 2012; Uzunoz and Akcay 2009) and import demand for rice in Uganda (Hyuha et al. 2017). In addition, the double log specification is used to examine the Japan's horticultural import performance. This is because it is a compromise with the reality in Japan that involves business activities of traders; hence, consumer behavior cannot generally be indicated (Honma 1991). The same behavior is observed in sago starch imports in Japan. The sago starch import business is controlled by traders, which may not directly indicate consumer preferences in the starch import business. Thus, a double-logarithmic linear function is suitable for this study. In addition, partial regression coefficients give direct elasticity in the double-logarithmic linear function, so the result can easily be evaluated (Akay et al. 2006). The double-logarithmic linear can be described in the form of equation (2):

$$
\operatorname{In}(\mathrm{y})=\beta_{0}+\beta_{1} \operatorname{In}(\mathrm{x})+\varepsilon
$$

in this equation, $\beta_{1}$ is the elasticity of $\mathrm{y}$ with respect to $\mathrm{x}$ with the interpretation of $\beta_{1}$ as $\% \Delta y=\beta_{1} \% \Delta x$ (Wooldridge 2013), where log-transformed of $y$ and $x$ are commonly referred to as elastic in econometrics (Benoit 2011). In statistics, it is a common way to transform variables into logarithmic to handle situations where a non-linear relationship exists between the independent and dependent variables (Mehmanpazir et al. 2019). Logarithmic transformations are used to transform a highly skewed variable into a more approximately normal variable (Benoit 2011).

The basic form of double-logarithmic linear is prevalent for estimating demand functions because of some convenient properties of the estimates. Through Equation (1), several variables of import demand in the equation model (2) are added. Thus, a double-log linear specification of sago starch import demand (QS) can be rewritten as equation (3):

$$
\operatorname{Ln}(Q S)=\beta_{0}+\beta_{1} \operatorname{Ln}(S P)+\beta_{2} \operatorname{Ln}(G D P)+\beta_{3} \operatorname{Ln}(E X R)+\beta_{4} \operatorname{Ln}\left(D P_{\mathrm{t}-1}\right)+\beta_{5} \operatorname{Ln}(C S V)+\beta_{6} \operatorname{Ln}(A G I N G)+\beta_{7}(P L)+\varepsilon
$$

It is necessary to investigate the time series data that the variable was generated by a stationary process, homogeneity, and multicollinearity. The statistical software STATA was then used for the estimation. Each variable was tested for a unit root using an Augmented Dickey-Fuller (ADF) procedure with the null hypothesis shows the variable contains a unit root. Since dummy variables can only take 0 or 1 values, thus, we did not test it for stationarity. The statistical result showed that the null hypothesis was rejected for all variables at the $10 \%$ significance level (Table 2).

The theoretical properties of homogeneity (Breusch-Pagan/ Cook-Weisberg) and multicollinearity were then examined for equation (3) as our first model. Although we accepted the null hypothesis that the variance of the residual is homogenous, the Variance Inflation Factor (VIF) of function I and function II had very high multicollinearity for some of the independent variables (Table 3). It was because some of the independent variables had the VIF values more than 5 and 1/VIF less than 0.10. Therefore, we removed some of the highly correlated independent variables and rewritten the new function and double-log linear model as per equation (4) and (5):

$$
\begin{aligned}
& \text { QS: f (SP, GDP, CSV, AGING, PL) } \\
& \operatorname{Ln}(\mathrm{QS})=\beta_{0}+\beta_{1} \operatorname{Ln}(S P)+\beta_{2} \operatorname{Ln}(G D P)+\beta_{3} \operatorname{Ln}(C S V)+\beta_{4} \operatorname{Ln}(A G I N G)+\beta_{5}(P L)+\varepsilon
\end{aligned}
$$

Table 2. Unit root test (Augmented Dickey-Fuller test) of variables

\begin{tabular}{cccc}
\hline Variable & Statistic & $5 \%$ critical value & $10 \%$ critical value \\
QS & -2.356 & -1.687 & -1.305 \\
SP & -1.388 & -1.687 & -1.305 \\
GDP & -2.461 & -1.687 & -1.305 \\
EXR & -1.473 & -1.687 & -1.305 \\
DP -1 & -3.761 & -1.687 & -1.305 \\
CSV & -3.053 & -1.687 & -1.305 \\
AGING & -2.666 & -1.687 & -1.305 \\
\hline
\end{tabular}

QS, import demand of sago starch; SP, price of imported sago starch; GDP, real gross income domestic product per capita; EXR, foreign exchange rate; $\mathrm{DP}_{\mathrm{t}-1}$, lagged domestic starch production; CSV, quantity of imported cassava starch; AGING, percentage of aging population rate in Japan. 
Table 3. Homogeneity and multicollinearity tests of several model functions

\begin{tabular}{|c|c|c|c|c|}
\hline \multirow[t]{2}{*}{ Function } & \multirow[t]{2}{*}{ Homogeneity } & \multicolumn{3}{|c|}{ Multicollinearity } \\
\hline & & Variable & VIF & 1/VIF \\
\hline I. QS: f (SP, GDP, EXR, DP $\left.{ }_{t-1}, \mathrm{CSV}, \mathrm{AGING}, \mathrm{PL}\right)$ & $\begin{array}{c}\text { Chi-square }(1)=1.52 \\
\text { Prob }>\text { Chi-square }=0.218\end{array}$ & $\begin{array}{c}\text { GDP } \\
\mathrm{DP}_{\mathrm{t}-1} \\
\text { EXR } \\
\text { PL } \\
\text { SP } \\
\text { CSV } \\
\text { AGING }\end{array}$ & $\begin{array}{r}25.18 \\
9.53 \\
6.69 \\
3.90 \\
2.59 \\
1.96 \\
1.47\end{array}$ & $\begin{array}{l}0.0397 \\
0.1049 \\
0.1495 \\
0.2561 \\
0.3856 \\
0.5111 \\
0.6822\end{array}$ \\
\hline II. QS: f (SP, GDP, EXR, CSV, AGING, PL) & $\begin{array}{c}\text { Chi-square }(1)=0.22 \\
\text { Prob }>\text { Chi-square }=0.637\end{array}$ & $\begin{array}{c}\text { GDP } \\
\text { EXR } \\
\text { PL } \\
\text { SP } \\
\text { CSV } \\
\text { AGING }\end{array}$ & $\begin{array}{r}10.49 \\
6.22 \\
3.60 \\
1.78 \\
1.53 \\
1.42\end{array}$ & $\begin{array}{l}0.0953 \\
0.1607 \\
0.2778 \\
0.5605 \\
0.6529 \\
0.7061\end{array}$ \\
\hline II. QS: f (SP, GDP, CSV, AGING, PL) & $\begin{array}{c}\text { Chi-square }(1)=0.22 \\
\text { Prob }>\text { Chi-square }=0.643\end{array}$ & $\begin{array}{c}\text { GDP } \\
\text { PL } \\
\text { SP } \\
\text { CSV } \\
\text { AGING }\end{array}$ & $\begin{array}{l}4.34 \\
3.60 \\
1.72 \\
1.38 \\
1.35\end{array}$ & $\begin{array}{l}0.2314 \\
0.2781 \\
0.5814 \\
0.7268 \\
0.7423\end{array}$ \\
\hline
\end{tabular}

VIF, variance inflation factor; QS, import demand of sago starch; SP, price of imported sago starch; GDP, real gross income domestic product per capita; EXR, foreign exchange rate; DP $\mathrm{t}_{\mathrm{t}-1}$, lagged domestic starch production; CSV, quantity of imported cassava starch; AGING, percentage of aging population rate in Japan.

The homogeneity and multicollinearity tests for the equation (5) finally showed that we accepted the null hypothesis that the variance of the residuals is homogenous with no multicollinearity among the explanatory variables because the VIF values were less than 5 and 1/VIF values were more than 0.10 (Table 3). Therefore, we used equation (5) as a final model for our further estimation.

\subsection{Data}

Annual time-series data from 1978 to 2017 were used in this study. All price and quantity data for sago starch and cassava starch were collected from Japanese trade statistical data of the Ministry of Finance. Sago starch is one of the agricultural commodities that adopt the Harmonized Schedule (HS) code under the International Convention on Harmonized Commodity Description and Coding System. In 1995, Harmonized Schedule (HS) codes of 1108.19.011, 1108.19.012, and 1108.19.019 were used for sago starch in international trade with the implementation of TRQ. Meanwhile, HS codes for cassava starch are 1108.14.010, 1108.14.020, and 1108.14.090. Data on aging population rate was collected from Statistical Bureau of Japan, Ministry of Internal Affairs and Communications. Meanwhile, the real GDP per capita and foreign exchange rate were obtained from the World Bank. Literature relevant to the field of study has also been investigated to supplement our research.

\section{Results and Discussion}

\subsection{Sago starch import demand in Japan}

Japan imported sago starch with a total average of 14,243 tons per year for 40 years (1978-2017). Sago starch is imported in the dry form without any processing treatment, such as oxidation, and is called raw starch (nama denpun) in Japan (Takahashi et al. 2015). Raw starch is then modified into oxidized starch (sanka denpun) through an oxidation process that exhibits lower viscosity and retrogradation rate and improves its whiteness through a bleaching effect. The starch modified through the oxidation method is widely used in food, such as dusting flour for noodles and dumpling skins (Takahashi et al. 2015). Meanwhile, utilization of sago starch for non-food industries is still very limited. It is used for film formation and adhesion properties when needed (Sondari et al. 2018).

Sago starch was considered the main Japanese import item, averaging 51\% of total starch imports at the beginning of $1963-$ 1965 (Trowbridge et al. 1967). However, the import of sago starch decreased significantly after 1985 as it was replaced by other starches such as corn starch. The import of sago starch reached a peak of 20,416 tons in 1979, falling dramatically to 


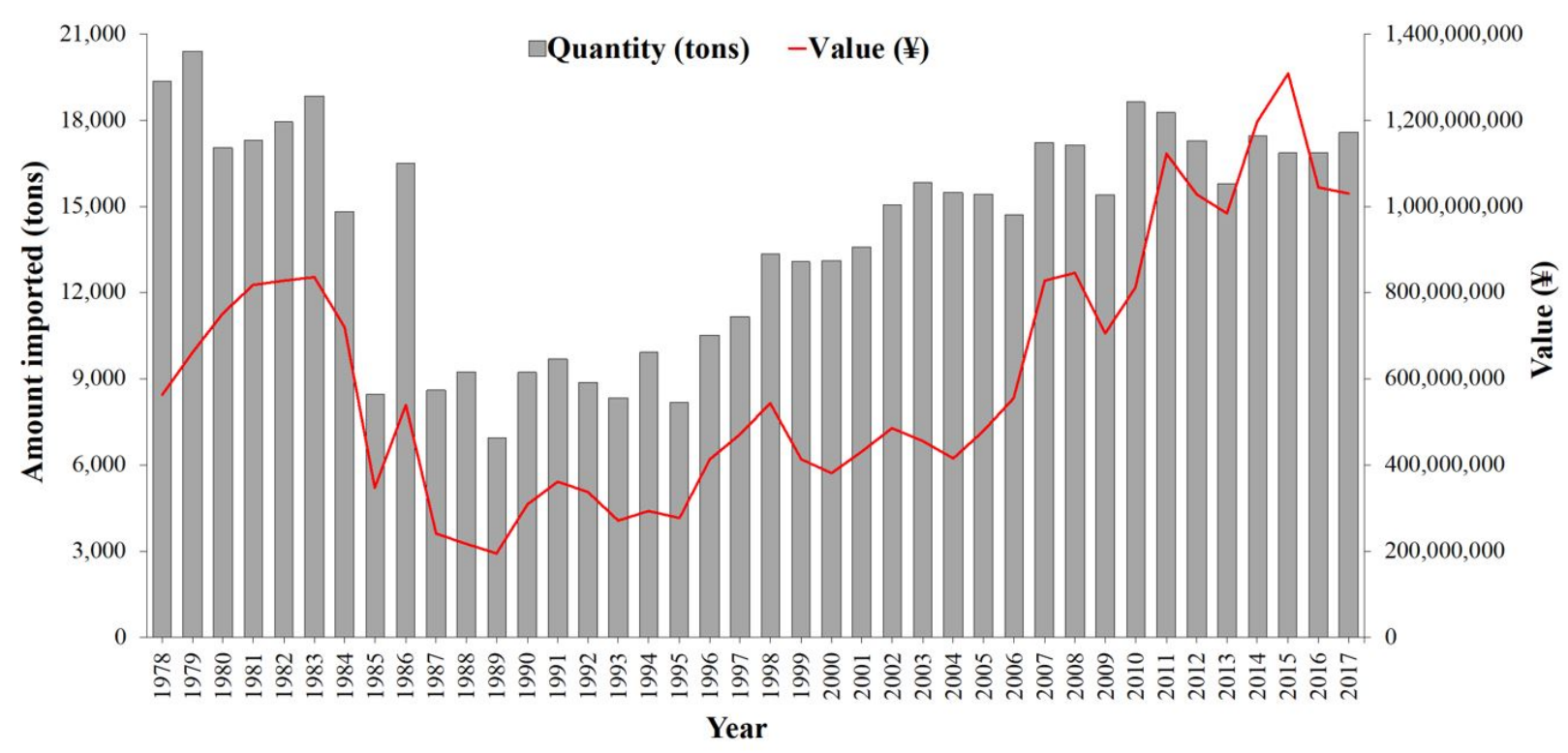

Figure 1. Sago starch import demand in Japan during 1978-2017.

6,968 tons in 1989 before increasing up to 2017 (Figure 1). The gradually increase in demand for sago starch after 1995 until the investigation period was due to the increasing starch demand from Japanese food industries. As a result, imports increased significantly from 8,194 tons in 1995 to 17,579 tons in 2017. Furthermore, when imported sago starch quantity was extremely low in 1989, the total value of sago starch also fell to its lowest point at a total value of 194 million yen. The value of imported sago starch gradually increased after 1995, with the highest value being 1.3 billion yen in 2015. Since sago starch is not actively used as food in Japan, sago starch importation is considered small. Several studies have stated that quality issues, competition with other starches, and insufficient demand for building factories locally in Japan are several reasons why the demand for imported sago starch is limited (BFPRO 2016; Takahashi et al. 2015).

Japan has been using the tariff rate quota system (TRQ) since joining the WTO in 1995. This resulted in the implementation of a tariff rate quota for starches under the implementation of the Uruguay Round Agriculture Agreement. Under tariffication, Japan applied a general tariff rate of 140 yen $/ \mathrm{kg}$ for importing raw starch. However, for sago starch, the tariff rate is about $25 \%$ within the tariff quota and $119 \mathrm{yen} / \mathrm{kg}$ if it is outside the tariff quota following WTO agreement tariffs. Meanwhile, there is no tariff applied when it is used for manufacturing sugar, dextrin, dextrin glue, soluble starch, roasted starch, and starch glue. In addition to human consumption, sago starch can also be used for animal feed, but it is reported that there is almost no utilization of sago starch for animal feed in Japan (Takahashi et al. 2015).

\subsection{Determinants of import demand for sago starch in Japan}

The raw dataset contained the annual value of each variable were created and then descriptive statistics of variables are calculated (Table 4). Furthermore, the calculation of the double-logarithmic linear model showed that the $R^{2}$ and adjusted $R^{2}$ of

Table 4. Descriptive statistics of variables

\begin{tabular}{ccccc}
\hline Variable & Mean & Std. dev & Min. & Max. \\
QS & $14,242.58$ & $3,806.174$ & 6,968 & 20,416 \\
SP & $41,458.03$ & $12,885.57$ & 23,480 & 77,686 \\
GDP & $3,462,215$ & $627,443.6$ & $214,967,3$ & $4,297,534$ \\
CSV & $112,280.2$ & $28,222.24$ & 48,970 & 155,983 \\
AGING & 3.295 & 0.7964505 & 0.9 & 4.4 \\
PL & 0.575 & 0.5006406 & 0 & 1 \\
\hline
\end{tabular}

QS, import demand of sago starch; SP, price of imported sago starch; GDP, real gross income domestic product per capita; CSV, quantity of imported cassava starch; AGING, percentage of aging population rate in Japan; PL, tariffication policy. 
Table 5. Estimated coefficient for sago starch import demand in Japan

\begin{tabular}{ccccc}
\hline Variable & Coefficient & Std. err & $t$-statistic & \\
SP & $.2794073^{*}$ & .1211116 & 2.31 & 0.027 \\
GDP & $-1.590088^{* *}$ & .314108 & -5.06 & 0.000 \\
CSV & .2130343 & .1390349 & 1.53 & 0.135 \\
AGING & $-.2944141^{*}$ & .1109784 & -2.65 & 0.012 \\
PL & $.5551886^{* *}$ & .1144567 & 4.85 & 0.000 \\
Constant & 28.02893 & 4.196839 & 6.68 & $=0.000$ \\
\hline$R^{2}$ & $=0.6536$ & & Adjusted $R^{2}$ & $=0.6026$ \\
Prob $>F$ & $=0.0000$ & DW & $=1.872$ \\
\hline
\end{tabular}

${ }^{*} p<0.05,{ }^{* *} p<0.01$.

SP, price of imported sago starch; GDP, real gross income domestic product per capita; CSV, quantity of imported cassava starch; AGING, percentage of aging population rate in Japan; PL, tariffication policy.

estimated import demand of sago starch in Japan are 0.6536 and 0.6026, respectively (Table 5). The $R^{2}$ implies that the estimated model explained $65.4 \%$ of the variability in the import demand for sago starch. We applied the Durbin-Watson $(d)$ test to calculate the autocorrelation in this study. The result indicated no autocorrelation problem at $5 \%$ significant level with $d$ value of $1.872\left(d_{L}: 1.175\right.$ and $d_{U}: 1.854$, thus $\left.d>d_{U}\right)$ in the estimated model.

The coefficient of the variables in the function represents direct elasticity with four variables that are found to be significant in affecting the demand for sago starch imports among a total of five independent variables. GDP per capita (GDP) and tariffication policy (PL) are significant factors influencing sago starch imports in Japan at the $1 \%$ level. Meanwhile, the price of sago starch (SP) and the aging population rate (AGING) have significant impacts at the level of $5 \%$. The quantity of imported cassava starch (CSV) is revealed to have no significant effect on sago starch import demand.

The variable of imported sago starch price is significantly related to the demand for sago starch imports in Japan. This result is also consistent with the findings of Ahad et al. (2017), Dutta and Ahmed (2004), and Rehman (2007). The positive sign suggests that a $1 \%$ increase in the import price of sago starch could result in about a $0.28 \%$ increase in the quantity of imported sago starch. We assume that the relationship between sago starch price and demand is inelastic, which means although the price goes up, sago starch import will remain to be done in order to meet consumption. A study by Takahashi et al. (1995) showed that sago starch has very interesting characteristics, which are shared by both root-tuber starches and cereal starches. Sago starch's viscosity characteristics are similar to potato starch, but its gel properties are similar to corn starch. These characteristics make sago starch suitable for noodles and dumpling skins, which are largely sold in Japan. BFRO (2016) stated that in 2012, a Japanese starch manufacturer launched an alternative material to substitute sago starch due to the high price, yet the trend of sago starch demand has been continuously rising. In addition, a study showed that noodle consumption, especially udon in Japan will continually increase in the future, which means the demand for sago starch as dusting flour for noodles will still exist in the future (Joetsu Starch Kabushikigaisha 2012).

Based on the results, the estimated coefficient of the gross income domestic product per capita (GDP) is significant to the quantity of imported sago starch. The negative sign suggests that a 1\% increase in GDP could result in about a 1.59\% decrease in the quantity of imported sago starch. This result is similar to a study in Malaysia where economic growth has a negative relationship with imports (Sulaiman and Saad 2009) but contrary to the result of Hyuha et al. (2017). The situation where income increases, but demand decreases could happen when the good is inferior. In terms of an inferior good, the demand decreases because consumers will be more willing to spend on more costly or better substitutes as income increases (Mankiw 2011). Based on this, we can assume that if consumer income in Japan rises, they would be more inclined towards another product (for example, kudzu starch) instead of sago starch, which is a little costly and well-known as healthy starch in Japan. In addition, the contribution of sago starch is expected to be small in since it is not part of basic food expenses for Japanese.

Several studies have indicated that the rate of import growth is affected by the size of the country's population (Alam et al. 2009; Faini et al. 1991; Feleke and Kilmer 2009). The Japanese population is characterized by a decreasing and highly aging population. The elderly dependency ratio in Japan is the highest in the OECD, projected to increase by 73\% in 2050 (OECD 2018), which will impact the demand for food in particular. The result showed that the variable of the aging population is significantly related to the demand for sago starch imports in Japan. Although it is expected that that demand for sago starch will increase when the aging of the population is rising, the result showed that the aging population rate has a negative relationship with import demand. It showed that a $1 \%$ increase of the AGING variable would result in sago starch import to 
decrease by $0.29 \%$. Notice that the AGING variable is already a percentage, which could mislead the reader. For example, if we assume that the aging population rate is $10 \%$, this figure should reach $10.1 \%$ for the AGING variable to increase by $1 \%$. Thus, resulting in a decrease of $0.29 \%$ in sago starch import. On the other hand, an increase in the aging population rate from $10 \%$ to $11 \%$ would result in an increase of the AGING variable by $10 \%$. Therefore, accounting for a decrease of $2.9 \%$ in sago starch import. The authors argue that unpopularity and limited access to sago products for older people are the main reasons why sago starch demand decrease. Sago starch is mainly sold for food manufacturers and noodle restaurants. Therefore, no particular product can be found at the retailer level and directed to older people. In addition, competition with other starches and lack of promotion on sago starch as a healthy product resulted in low demand of imported sago starch for aging people in Japan. We expect with better promotion and availability of various sago starch products will likely affect the demand for sago starch in the future.

Based on Table 5, the estimated coefficient of a dummy variable for tariff-rate quota is significantly related to the quantity of imported sago starch. It is well known that tariff-rate quotas are used as a trade barrier imposed on imported products to protect domestic production (Ederington and Ruta 2016). In fact, several studies have mentioned that the high tariff rate is the main reason for the small import volume (BFPRO 2016; Koo et al. 2001; Takahashi et al. 2015) although no tariffs to be applied for imported sago starch that is used for manufacturing sugar, dextrin, soluble starch, and starch glue in Japan. The price of imported sago starch for food purposed is raised by the tariff rate, which forces buyers to shoulder the whole burden of the higher price. It could be the reason why Japanese traders tend to avoid importing more than the quota limits. However, Haraoka (2011) and Pudjiastuti et al. (2013) argued that high tariffs would increase the prices of imports while allowing domestic producers to sell their products at higher prices. It is widely known that the Japanese government established a maximum tariff rate, calculated on the difference between domestic and international prices, to protect the local agriculture industry (Yamashita 2013), specifically the sweet potato and potato starch industries. The establishment of the Agricultural Products Price Stabilization Act in 1953 and the adjustment of domestic production of potato starch and sweet potato starch policy in 1965 successfully promoted potato starch and sweet potato starch utilization in Japanese food industries (WTO 1988). Therefore, the effectiveness of the Japanese governmental to protect domestic market through import restrictions and high tariff rate will clearly have impact on sago starch import demand.

In terms of imported cassava starch, the estimated coefficient is not statistically significant to the demand of sago starch. This result is similar to study from Hyuha et al. (2017) but contrary to the result of Baiyegunhi and Sikhosana (2012). The quantity of imported cassava starch has not been proven to have an impact on the demand of sago starch since sago starch import has continued to increase over the last few years. Cassava starch is the main Japanese starch import item, averaged 75\% of total starch imports from 1978-2017 with various utilizations in the Japanese industries such as an ingredient in sweets, thickening stabilizer, and binding agent. Meanwhile, sago starch is only averaged $9.6 \%$ from total starch imports during the same years. The different applications and purpose in the utilization on each starch could be the reason why cassava import volume, whether increasing or decreasing, will not significantly affect the demand for sago starch in Japan.

\section{Conclusion}

Japan is one of the world's biggest importers of starches including sago starch. This study shows that the prices of sago starch, GDP per capita, aging population rate as well as tariffication policy are significant factors influencing sago starch imports in Japan. Since sago starch is not commonly sold at the retail level, we suggest that active promotion of its cooking properties and health benefits should be undertaken in order to make sago starch more widely known. We also should consider how sago starch can be economically attractive for the Japanese industries. In addition, improvement of sago starch quality and product differentiation should be pursued to meet the quality standards of the purchaser and render it more competitive in Japan’s import market.

\section{Acknowledgements}

This study was supported by JSPS KAKEN Grant JP18KT0041.

\section{References}

Ahad, M., Afza, T., Shahbaz, M., 2017. Financial development and estimation of import demand function in Pakistan: Evidence 
from combined cointegration and causality tests. Global Business Review 18, 118-131.

Akay, M., Gunduz, O., Esengun, K., 2006. A regression analysis of the economic factors effecting the import of forest industry products in Turkey. Journal of Applied Sciences 6, 357-361.

Alam, M. M., Uddin, M. G. S., Taufique, K. M. R., 2009. Import inflows of Bangladesh: The gravity model approach. International Journal of Economics and Finance 1, 131-139.

Anugoolprasert, O., Kinoshita, S., Naito, H., Shimizu, M., Ehara, H., 2012. Effect of low pH on the growth, physiological characteristics and nutrient absorption of sago palm in a hydroponic system. Plant Production Science 15, 125-131.

Baiyegunhi, L. J. S., Sikhosana, M., 2012. An estimation of import demand function for wheat in South Africa: 1971-2007. African Journal of Agricultural Research 7, 5175-5180.

Benoit, K., 2011. Linear regression models with logarithmic transformations. Available at: https://kenbenoit.net/assets/ courses/ME104/logmodels2.pdf

Business of Forest Products [BFPRO], 2016. Sago starch. Available at: https://jifpro.or.jp/bfpro/sn/sn-17/1522/

Chew, T., Isa, A. H. M., Mohayidin, M. G., 1999. The sago industry in Malaysia: Present status and future prospects. Proceedings of the 7th International Working Conference on Stores-Product Protection, Chengdu, China.

Choi, J., Sumner, D. A., 2016. Opening markets while maintaining protection: Tariff rate quotas in Korea and Japan. Agricultural and Resource Economics Review 29, 91-102.

Custom and Tariff Bureau, 2020. Trade statistics of Japan. Available at: https://www.customs.go.jp/toukei/info/index_e.htm

Dezhbakhsh, H., Thursby, J. G., 1994. Testing for autocorrelation in the presence of lagged dependent variables: A specification error approach. Journal of Econometrics 60, 251-272.

Durbin, J. 1970. Testing for serial correlation in least-squares regression when some of the regressors are lagged dependent variables. Econometrica 38, 410-421.

Dutta, D., Ahmed, N., 2004. An aggregate import demand function for India: A cointegration analysis. Applied Economics Letters 11, 607-613.

Ederington, J., Ruta, M., 2016. Non-Tariff Measures and the World Trading System. World Bank, Washington, DC.

Ehara, H. 2009. Potency of sago palm as carbohydrate resource for strengthening food security program. Jurnal Agronomi Indonesia 37, 209-219.

Ehara, H., Morita, O., Komada, C., Goto, M., 2001. Effect of physical treatment and presence of the pericarp and sarcotesta on seed germination in sago palm (Metroxylon sagu Rottb.). Seed Science and Technology 29, 83-90.

Faini, R., Melo, J. D., Senhadji, A., Stanton, J., 1991. Growth-oriented adjustment programs: A statistical analysis. World Development 19, 957-967.

Feleke, S. T., Kilmer, R. L., Goldsmith, P. D., 2009. The Japanese market for imported fruit juices. International Food and Agribusiness Management Review 12, 1-28.

Goktolga, Z. G., 2006. A analysis of import demand for meat and meat product in Turkey. Journal of Agronomy 5, 98-100.

Goldstein, M., Khan, M. S., 1985. Income and price effects in foreign trade. In: Jones, R. W., Kenen, P. B. (Eds.), Handbook of International Economics. Elsevier Science Publications, New York, NY.

Hirao, K., Kondo, T., Kainuma, K., Takahashi, S., 2018. Starch properties and uses as food for human health and welfare. In: Ehara, H., Toyoda, Y., Johnson, D. (Eds), Sago Palm: Multiple Contributions to Food Security and Sustainable Livelihoods. Springer, Singapore.

Haraoka, N., 2011. The best policy to protect Japanese agriculture. Available at: https://www.jef.or.jp/journal/pdf/ 178th_Economic_Focus.pdf

Hong, P., 1999. Import Elasticities Revisited. United Nations, New York, NY.

Honma, M., 1991. Growth in Japan's Horticultural Trade with Developing Countries: An Economic Analysis of the Market. International Food Policy Research Institute, Washington, DC.

Hyuha, T. S., William, E., Grace, B. K., 2017. Determinants of import demand of rice in Uganda. International Journal of Applied and Pure Science and Agriculture 3, 75-81.

Joetsu Starch Kabushikigaisha, 2012. Fundamental knowledge of dusting flour. Available at: https://www.alic.go.jp/johod/ joho08_000147.html

Karkacier, O., 2000. An analysis of import demand for dairy products in Turkey. Turkish Journal of Agriculture and Forestry 24, 421-427.

Khan, M. S., 1974. Import and export demand in developing countries. Staff Papers, 21, 678-693.

Kizilaslan, H., Kizilaslan, N., 2006. An analysis of import demand in vegetal oil and products industry in Turkey. Journal of 
Applied Sciences 6, 905-910.

Konuma, H., 2018. Status and outlook of global food security and the role of underutilized food resources: Sago palm. In: Ehara, H., Toyoda, Y., Johnson, D. (Eds), Sago Palm: Multiple Contributions to Food Security and Sustainable Livelihoods. Springer, Singapore.

Koo, W. W., Mao, W., Sakurai, T., 2001. Wheat demand in Japanese flour milling industry: A production theory approach. Agricultural Economics 24, 167-178.

Mankiw, N. G., 2012. Principles of Economics. 5th ed. South-Western Cengage Learning, Mason, OH.

Mehmanpazir, F., Khalili-Damghani, K., Hafezalkotob, A., 2019. Modeling steel supply and demand functions using logarithmic multiple regression analysis (Case study: Steel industry in Iran). Resources Policy 63, 1-20.

Ningrum, I. H., Irianto, H., Riptanti, E. W., 2018. Analysis of soybean production and import trends and its import factors in Indonesia. IOP Conference Series: Earth and Environmental Science 142, 1-8.

Observatory of Economic Complexity [OEC], 2017. Starches. Available at: https://oec.world/en/profile/hs92/21108

Organisation for Economic Cooperation and Development [OECD], 2018. Japan: Promoting inclusive growth for an ageing society. Available at: https://www.oecd.org/about/secretary-general/BPS-Japan-EN-April-2018.pdf

Pudjiastuti, A. Q., Anindita, R., Hanani, N., Kaluge, D., 2013. Changes effect of sugar import tariff in Indonesia. Russian Journal of Agricultural and Socio-Economic Sciences 15, 31-38.

Rehman, H. U., 2007. An econometric estimation of traditional import demand function for Pakistan. Pakistan Economic and Social Review 45, 245-256.

Sondari, D., Triwulandari, E., Ghozali, M., Sampora, Y., Iltizam, I., Masruchin, N., 2018. The effect of oxidation on sago starch and its application as edible film. Jurnal Sains Materi Indonesia 20, 1-7.

Sulaiman, M., Saad, N. M., 2009. An analysis of export performance and economic growth of Malaysia using co-integraton and error correction models. The Journal of Developing Areas 43, 217-231.

Takahashi, S., Hirao, K., Kainuma, K., 1995. Physico-chemical properties and cooking quality of sago starch. Sago Palm 3, 72-82.

Takahashi, S., Kondo, T., Hirao, K., Ohmi, M., Konoo, S., Kainuma, K., 2015. Starch properties and uses. In: The Society of Sago Palm Studies (Ed), The Sago Palm: The Food and Environmental Challenges of the 21st Century. Kyoto University Press, Kyoto, Japan.

Takamura, T., 1990. Present research activities and the problems on sago palm. Japanese Journal of Tropical Agriculture 34, 51-58.

Tang, T. C., 2008. Aggregate import demand function for Japan: A cointegration re-investigation. Global Economic Review 37, 363-377.

Tanyeri-Abur, A., Rosson, P., 1997. Forecasting Mexican Import Demand for Dairy Products. Texas A\&M University, College Station, TX.

Trisia, M. A., Metaragakusuma, A. P., Osozawa, K., Bai, H., 2017. Do small-scale farmers want to plant sago palm? An empirical analysis of the factors influencing farmer participation in Luwu Utara Regency, Indonesia. Journal of Agriculture and Crops 3, 97-109.

Trowbridge, A. B., McQuade, L., Borum, R. L., 1967. Starch and Related Products in Related Countries. US Department of Commerce, Washington, DC.

Ugur, A., 2008. Import and economic growth in Turkey: Evidence from multivariate VAR analysis. Journal of Economics and Business 11, 54-75.

Uzunoz, M., Akcay, Y., 2009. Factors affecting the import demand of wheat in Turkey. Bulgarian Journal of Agricultural Science 15, 60-66.

Wooldridge, J. M., 2013. Introductory Econometrics: A Modern Approach. 5th Ed. South-Western College Publishing, Maxon, $\mathrm{OH}$.

World Trade Organization [WTO], 1988. Japan - Restrictions on imports of certain agricultural products. Available at: https://www.wto.org/english/tratop_e/dispu_e/gatt_e/86agricl.pdf

Yamashita, K., 2013. Tariffs on agricultural products. Available at: https://www.canon-igs.org/en/column/macroeconomics/ 20130314_1779.html 